\title{
KEBIJAKAN HUKUM PIDANA DALAM PEMBERANTASAN TINDAK PIDANA KORUPSI
}

\author{
Andi Febriansyah Al Sabah AZ \\ Mahasiswa Pascasarjana UMI
}

\begin{abstract}
As a sovereign country, Indonesia holds a great and noble idea to create common welfare as the main basic of the policy making, including legislative policy to keep the effort in improving society welfare as the constitutional right of every single citizen of Indonesia. However, the idea may be barred by the corruption rapidly done that is breaking the life of the nation. Not only damaging the finance sector or national economy but also breaking people economy and becoming the threat to the national and International stability.

For those above reasons, a policy on the formulation of criminal law concerning the formulation of criminal offense in particular is necessary. Therefore, the problems are focusing on two main issues: the policy on the formulation of corruption in the present and in the future regulations.

The aim of the research is to analyze the formulation policy related with the eradication of corruption today and to know and to analyze the formulation policy to be done in prevention of corruption in the future. This research is using the normative-juridical method asserting law as the norm as the guidance of human conduct focusing on the secondary data obtained from regulations as the primary resources.

From the research findings the policy on the formulation of criminal law in eradicating the corruption is still weak. Therefore, some reformation is necessary by stressing on the formulation of criminal offense on the element of 'damaging the country'. Considering the rapid growth of corruption year by year, The Concept of Penal Code is the right criminal law policy in eradicating corruption in the future.
\end{abstract}

Keyword:

Formulation policy, Prevention, Corruption.

\begin{abstract}
Abstrak
Sebagai Negara yang berdaulat, Indonesia memiliki cita-cita yang mulia yaitu menciptakan kesejahteraan umum yang merupakan landasan utama bagi setiap pengambilan kebijakan, termasuk kebijakan legislatif untuk terus berupaya meningkatkan taraf kehidupan masyarakat yang merupakan hak konstitusional setiap warga negara Indonesia. Namun demikian, cita-cita tersebut dapat terhambat oleh tindakan korupsi yang berkembang sangat cepat,
\end{abstract}


bahkan merusak sendi-sendi kehidupan bangsa, dan tidak hanya merugikan keuangan atau perekonomian negara, tetapi merusak perekonomian rakyat, serta menjadi ancaman bagi stabilitas Nasional dan internasional.

Untuk itu diperlukan kebijakan hukum pidana khususnya mengenai tindak pidana korupsi, karena itu permasalahan difokuskan pada dua hal pokok yaitu bagaimana kebijakan hukum tindak pidana korupsi dalam perundang-undangan yang berlaku saat ini dan yang akan datang.

Tujuan penelitian adalah menganalisa kebijakan hukum pidana yang berkaitan dengan pemberantasan tindak pidana korupsi saat ini serta untuk mengetahui dan menganalisa mengenai kebijakan formulasi yang harus dilakukan dalam rangka pemberantasan tindak pidana korupsi yang akan datang. Penelitian ini menggunakan metode yuridis normatif, dengan mengkonsepsikan hukum sebagai kaidah norma yang merupakan patokan prilaku manusia, dengan menekankan pada sumber data sekunder yang dikumpulkan dari sumber primer yaitu perundang-undangan.

Berdasarkan hasil penelitian bahwa kebijakan hukum pidana dalam pemberantasan tindak pidana korupsi masih terdapat beberapa kelemahan, sehingga diperlukan pembaharuan dengan menekankan rumusan tindak pidana pada unsur "merugikan negara". Mengingat perkembangan korupsi semakin cepat dari tahun ke tahun, maka Konsep KUHP dirasakan sebagai kebijakan hukum pidana yang tepat bagi penanggulangan tindak pidana korupsi yang akan datang.

Kata Kunci:

Kebijakan Hukum, Pidana, Pemberantasan, Tindak Pidana Korupsi

\section{LATAR BELAKANG}

$\Gamma$ - 7 erbentuknya negara Indonesia tidak lain memiliki suatu tujuan yang mulia yaitu mendorong dan menciptakan kesejahteraan umum dalam payung Negara Kesatuan Republik Indonesia yang berlandaskan Pancasila.

Tujuan atau cita-cita tersebut tercermin dalam pembukaan Undang- undang Dasar Negara Republik Indonesia Tahun 1945 dalam alinea ke-4 (empat) yaitu:

Kemudian daripada itu untuk membentuk suatu Pemerintahan Negara Indonesia yang melindungi segenap bangsa Indonesia dan seluruh tumpah darah Indonesia dan untuk memajukan kesejahteraan umum, mencerdaskan kehidupan bangsa dan ikut melaksanakan ketertiban dunia yang berdasarkan kemerdekaan, perdamaian abadi dan keadilan sosial,...... ${ }^{1}$

\footnotetext{
${ }^{1}$ Persandingan Undang-undang Dasar Negara Republik Indonesia Tahun 1945, Lembaga Informasi Nasional Republik Indonesia, 2000:2-3
} 
Kesejahteraan bagi seluruh rakyat tanpa kecuali merupakan landasan utama bagi setiap pengambilan kebijakan termasuk kebijakan legislatif untuk terus berupaya meningkatkan taraf kehidupan masyarakat yang pada dasarnya merupakan hak konstitusional setiap warga negara Indonesia.

Perlindungan terhadap segenap bangsa dan tumpah darah melalui perangkat hukum yang berlaku merupakan hal yang mutlak untuk diwujudkan, tidak ada artinya kata-kata "melindungi segenap bangsa dan tumpah darah" jika ternyata masih ada penderitaan yang dirasakan oleh rakyat berupa ketimpanganketimpangan hak-hak ekonomi yang mencerminkan ketidaksejahteraan bagi seluruh rakyat Indonesia. ${ }^{2}$

Perlu penjabaran lebih rinci secara hukum, agar kewajiban konstitusional tersebut benar-benar dijalankan secara baik, dengan menciptakan praktek-praktek pemerintahan yang terbuka, transparan dan senantiasa bertanggung jawab atas kepentingan masyarakat secara luas, ${ }^{3}$ yang titik akhirnya adalah kesejahteraan secara nyata bagi masyarakat luas dengan berpedoman pada prinsip-prinsip keadilan sosial berdasarkan Ketuhanan Yang Maha Esa.

Untuk mewujudkan cita-cita luhur tersebut, yang berkaitan dengan manifestasi atas kesejahteraan seluruh rakyat Indonesia maka lahirlah suatu pedoman bagi Penyelenggaraan Negara yang Bersih dan Bebas Korupsi, Kolusi, dan Nepotisme yang dirumuskan dalam Undang-Undang Nomor 28 Tahun 1999. Dalam undangundang tersebut memuat prinsip-prinsip atau asas-asas Kepastian hukum, Tertib Penyelenggaraan Negara, Kepentingan Umum, Keterbukaan, Proporsionalitas, Profesionalitas, dan Akuntabilitas

Pedoman mengenai Penyelenggaraan Negara yang Bersih dan Bebas KKN ini menjadi penting dan sangat diperlukan untuk menghindari praktek- praktek Kolusi, Korupsi dan Nepotisme tidak saja melibatkan pejabat yang bersangkutan tetapi juga oleh keluarga dan kroninya, yang jika dibiarkan maka rakyat Indonesia akan berada dalam posisi yang sangat dirugikan.

Untuk lebih menjamin pelaksanaan pemerintahan yang bersih dan bebas korupsi, kolusi, dan nepotisme maka, dibentuknya Undang-Undang Nomor 31 Tahun 1999 sebagaimana yang diperbaharui dengan Undang-Undang Nomor 20 Tahun 2001 Tentang Pemberantasan Tindak Pidana Korupsi, sebagai pengganti Undang-Undang nomor 3 Tahun 1971. Lahirnya undang-undang ini diharapkan dapat mempercepat pertumbuhan kesejahteraan rakyat, dengan sebuah penanggulangan terhadap sifat jahat yang terkandung dalam korupsi.

Bentuk-bentuk korupsi, terutama dalam lingkup suap merupakan penyakit yang sangat akut bagi bangsa Indonesia, karena hampir di setiap lembaga pelayanan publik suap sudah menjadi hal yang biasa, yang pada akhirnya ada kesulitan-

2 Ridwan, "Kebijakan Penegakan Hukum Pidana dalam Pemberantasan Tindak Pidana Korupsi di Indonesia "Jurnal Jure Humano, Volume1 No.1, 2009:74

${ }^{3}$ bid. hlm.74 
kesulitan dalam mendeteksi korupsi, sehingga pencegahannya pun makin sulit dilakukan, sehingga korupsi terus berkembang dan menjalar dalam setiap aspek kehidupan.

Kondisi ini tampaknya sangat sesuai dengan semangat pembentuk undangundang, yaitu melalui kebijakan legislatif dengan menetapkan undang-undang nomor 31 tahun 1999 sebagaimana yang telah diperbaharui dengan undang-undang nomor 20 tahun 2001 tentang Pemberantasan Tindak pidana Korupsi yang di dalamnya mencantumkan sifat melawan hukum secara materiel. Hal ini sebagaimana dirumuskan dalam penjelasan umum yang menegaskan bahwa, agar dapat menjangkau berbagai modus operandi penyimpangan keuangan negara atau perekonomian negara yang semakin canggih dan rumit, maka tindak pidana yang diatur dalam undang-undang ini dirumuskan sedemikian rupa sehingga meliputi perbuatan-perbuatan memperkaya diri sendiri atau orang lain atau suatu korporasi secara "melawan hukum" dalam pengertian formil dan materil. Dengan perumusan tersebut, pengertian melawan hukum dalam tindak pidana korupsi dapat pula mencakup perbuatan-perbuatan tercela yang menurut perasaan keadilan masyarakat harus dituntut.

\section{METODE PENELITIAN}

Karena sasaran utama dalam penelitian ini pada masalah kebijakan legislatif yaitu mengenai perundang-undangan dalam menetapkan dan merumuskan tindak pidana korupsi, maka pendekatannya terutama ditempuh lewat pendekatan yuridis normatif.

\section{HASIL PENELITIAN DAN PEMBAHASAN}

a. Rumusan tindak pidana korupsi dan ruang lingkupnya dalam Undangundang Pemberantasan Tindak Pidana Korupsi Indonesia

Kebijakan formulasi hukum pidana dalam upaya menanggulangi tindak pidana korupsi saat ini, sesungguhnya telah mengalami berbagai perubahan, yang mana perubahan tersebut dilakukan mengingat perkembangan korupsi yang demikian cepat. Bahkan menurut beberapa ahli atau pakar hukum pidana dan kriminologi sebagaimana yang telah diuraikan dalam Bab I dan Bab II korupsi digambarkan sebagai suatu penyakit yang dalam perkembangannya bukan saja merusak atau merugikan keuangan dan perekonomian negara, akan tetapi telah melampaui batas-batas tersebut yakni merusak atau merugikan perekonomian rakyat.

Perubahan-perubahan kebijakan hukum pidana dalam penanggulangan tindak pidana korupsi, yang disebabkan oleh perkembangan korupsi yang demikian cepat dan disesuaikan dengan kebutuhan masyarakat guna peningkatan kesejahteraan masyarakat dilukiskan pada konsiderans beberapa perundang-undangan mengenai pemberantasan tindak pidana korupsi, misalnya sebagai berikut: 
1. Konsiderans Undang-undang Nomor 3 Tahun 1971:

a. Bahwa perbuatan-perbuatan korupsi sangat merugikan keuangan/ perekonomian negara dan menghambat pembangunan nasional;

b. Bahwa Undang-undang No. 24 Prp. Tahun 1960 tentang Pengusutan, Penuntutan dan Pemeriksaan Tindak Pidana Korupsi berhubung dengan perkembangan masyarakat kurang mencukupi untuk dapat mencapai hasil yang diharapkan, dan oleh karenanya undang-undang tersebut perlu diganti.

2. Konsiderans Undang-undang Nomor 31 Tahun 1999:

a. Bahwa tindak pidana korupsi sangat merugikan keuangan Negara atau perekonomian Negara dan menghambat pembangunan nasional, sehingga harus diberantas dalam rangka mewujudkan masyarakat adil dan makmur berdasarkan Pancasila dan Undang-Undang Dasar 1945;

b. Bahwa akibat tindak pidana korupsi yang terjadi selama ini selain merugikan keuangan Negara atau perekonomian negara, juga menghambat pertumbuhan dan kelangsungan pembangunan nasional yang menuntut efisiensi tinggi;

c. Bahwa Undang-undang Nomor 3 Tahun 1971 tentang Pemberantasan Tindak Pidana Korupsi sudah tidak sesuai lagi dengan perkembangan kebutuhan hukum dalam masyarakat, karena itu perlu diganti dengan Undang-undang Pemberantasan Tindak Pidana Korupsi yang baru sehingga diharapkan lebih efektif dalam mencegah dan memberantas tindak pidana korupsi;

3. Konsiderans Undang-undang Nomor 20 Tahun 2001:

a. Bahwa tindak pidana korupsi yang selama ini terjadi secara meluas, tidak hanya merugikan keuangan negara, tetapi juga telah merupakan pelanggaran terhadap hak-hak sosial dan ekonomi masyarakat secara luas, sehingga tindak pidana korupsi perlu digolongkan sebagai kejahatan yang pemberantasannya harus dilakukan secara luar biasa;

b. Bahwa untuk lebih menjamin kepastian hukum, menghindari keragaman penafsiran hukum dan memberikan perlindungan terhadap hak-hak sosial dan ekonomi masyarakat, serta perlakuan secara adil dalam memberantas tindak pidana korupsi, perlu diadakan perubahan atas Undang-undang Nomor 31 Tahun 1999 tentang Pemberantasan Tindak Pidana Korupsi;

c. Bahwa berdasarkan pertimbangan sebagaimana dimaksud dalam huruf a dan huruf $b$, perlu membentuk Undang-undang tentang Perubahan Atas Undang-undang Nomor 31 Tahun 1999 tentang Pemberantasan Tindak Pidana Korupsi.

Pertimbangan mengenai perlunya perumusan tindak pidana korupsi, sebagaimana diungkapkan dalam konsiderans dalam perundang-undangan di atas 
menunjukkan adanya keprihatinan atas tindak pidana korupsi yang telah merugikan keuangan negara dan menghambat pembangunan nasional. kemudian perubahanperubahan mengenai tindak pidana korupsi yang dirumuskan dapat terlihat dari rumusan tindak pidana korupsi dalam Pasal 1 ayat (1) Undang-Undang Nomor 3 Tahun 1971 sebagai berikut:

a. Barangsiapa dengan melawan hukum melakukan perbuatan memperkaya diri sendiri atau orang lain, atau suatu Badan, yang secara langsung atau tidak langsung merugikan keuangan negara dan atau perekonomian negara, atau diketahui atau patut disangka olehnya bahwa perbuatan tersebut merugikan keuangan negara atau perekonomian negara;

b. Barangsiapa dengan tujuan menguntungkan diri sendiri atau orang lain atau suatu Badan, menyalahgunakan kewenangan, kesempatan atau sarana yang ada padanya karena jabatan atau kedudukan, yang secara langsung atau tidak langsung dapat merugikan keuangan negara atau perekonomian negara.

Perumusan mengenai tindak pidana korupsi dalam Undang-Undang Nomor 3 Tahun 1971 tersebut, meletakkan korupsi sebagai delik materiel. Konsekuensi dari rumusan tersebut adalah korupsi harus dibuktikan terlebih dahulu apakah telah merugikan keuangan negara atau tidak. Rumusan dengan model ini mengakibatkan tidak efektifnya penanggulangan tindak pidana korupsi, terutama yang dilakukan oleh para pejabat negara.

Ketidakefektifan pemberantasan korupsi dengan melandaskan pada rumusan delik materil tersebut, kemudian melahirkan kebijakan pemberantasan korupsi yang baru yakni dengan merumuskan korupsi sebagai delik formil. Pendirian pembentuk undang-undang mengenai pemberantasan tindak pidana korupsi ini juga tampaknya disemangati oleh pergerakan tindak pidana korupsi yang dalam perkembangannya tidak saja merugikan keuangan atau perekonomian negara tapi sudah merusak hakhak sosial dan hak-hak ekonomi rakyat. kondisi inilah yang kemudian mengubah arah kebijakan hukum pidana, di mana tindak pidana korupsi yang pada awalnya dirumuskan berdasarkan delik materil diubah menjadi delik formil. Hal tersebut terlihat dalam Pasal 2 dan Pasal 3 Undang-undang Nomor 31 tahun 1999 jo. Undangundang Nomor 20 Tahun 2001 tentang Pemberantasan tindak Pidana Korupsi sebagai berikut:

Pasal 2 ayat (1):

Setiap orang yang secara melawan hukum melakukan perbuatan memperkaya diri sendiri atau orang lain atau suatu korporasi yang dapat merugikan keuangan negara atau perekonomian negara.

Pasal 3:

Setiap orang yang dengan tujuan menguntungkan diri sendiri atau orang lain atau suatu korporasi, menyalahgunakan kewenangan, kesempatan atau sarana yang ada 
padanya karena jabatan atau kedudukan yang dapat merugikan keuangan negara atau perekonomian negara.

Kedua rumusan tersebut menempatkan tindak pidana korupsi sebagai delik formil, di mana perbuatan korupsi tetap dipidana, sekalipun tidak terjadi kerugian terhadap keuangan atau perekonomian negara. Hal ini sesuai dengan penjelasan Pasal 2 ayat (1) Undang-undang Nomor 31 Tahun 1999 bahwa kata "dapat" sebelum frase "merugikan keuangan dan atau perekonomian Negara menunjukkan bahwa tindak pidana korupsi merupakan delik formil, yaitu adanya tindak pidana korupsi cukup dengan dipenuhinya unsur-unsur perbuatan yang sudah dirumuskan bukan dengan timbulnya akibat.

Secara lebih rinci Barda Nawawi Arief merinci ruang lingkup tindak pidana korupsi tersebut sebagai berikut :4

\section{1) Undang-undang Nomor 3 Tahun 1971:}

Pasal 1:

1. a. Barangsiapa:

- Dengan melawan hukum;

- Memperkaya diri sendiri, orang lain, atyau suatu badan;

- Yang langsung atau tidak langsung merugikan keuangan dan atau perekonomian Negara; atau

- Diketahui atau patut disangka olehnya bahwa perbuatan tersebut merugikan keuangan atau perekonomian Negara

b. Barangsiapa :

- Dengan tujuan menguntungkan diri sendiri, orang lain, atau suatu badan;

- Menyalahgunakan kewenangan, kesempatan, atau sarana yang ada padanya karena jabatan atau kedudukan;

- Yang langsung atau tidak langsung dapat merugikan keuangan dan atau perekonomian Negara.

c. Barangsiapa :

- Melakukan kejahatan dalam Pasal 209, 210, Pasal 387, 388, Pasal 415 sampai dengan Pasal 420, Pasal 425 dan Pasal 435 KUHP;

d. Barangsiapa :

- Member hadiah/janji ;

- Kepada Pegawai Negeri dalam Pasal 2;

- Dengan mengingat kekuasaan atau wewenang yang melekat pada jabatannya atau kedudukannya, atau oleh si pemberi dianggap melekat jabatan atau kedudukannya.

e. Barangsiapa :

- Tanpa alasan wajar;

\footnotetext{
${ }^{4}$ Barda Nawawi Arief, Kapita Selekta Hukum Pidana, Bandung, Citra Aditya Bakti, 2003:97-106
} 
- Dalam waktu yang sesingkat-singkatnya setelah menerima pemberian atau jani;

- Yang diberikan kepadanya seperti tersebut dalam pasal 418, 419, dan Pasal 420 KUHP;

- Tidak melaporkan pemberian atau janji tersebut kepada yang berwajib

2. Barangsiapa melakukan percobaan atau permufakatan untuk melakukan tindak pidana tersebut dalam ayat (1) a, b, c, d, e pasal ini.

\section{2) Undang-undang Nomor 31 Tahun 1999:}

A. Tindak Pidana Korupsi (Bab II, Pasal 2 sampai dengan Pasal 20);

1. Pasal 2 (berasal dari Pasal 1sub 1a Undang-Undang Nomor 3 Tahun 1971):

Setiap orang:

- Yang secara melawan hukum,

- Melakukan perbuatan memperkaya diri sendiri, orang lain atau korporasi,

- Yang dapat merugikan keuangan atau perekonomian negara.

2. Pasal 3 (berasal dari Pasal 1sub 1b Undang-Undang Nomor 3 Tahun 1971): Setiap orang:

- Yang dengan tujuan menguntungkan diri sendiri, orang lain, atau korporasi,

- Menyalahgunakan kewenangan, kesempatan atau sarana yang ada padanya karena jabatan atau kedudukan,

- Yang dapat merugikan keuangan atau perekonomian negara

3. Pasal 4 (Pasal baru) :

- Pengembalian kerugian keuangan atau perekonomian negara tidak menghapuskan pemidanaan Pasal 2 dan Pasal 3.

4. Pasal 5 (berasal dari Pasal 1sub 1c Undang-Undang Nomor 3 Tahun 1971 jo. Pasal 209 KUHP).

5. Pasal 6 (berasal dari Pasal 1sub 1c Undang-Undang Nomor 3 Tahun 1971 jo. Pasal 210 KUHP).

6. Pasal 7 (berasal dari Pasal 1sub 1c Undang-Undang Nomor 3 Tahun 1971 jo. Pasal 387 dan Pasal 388 KUHP).

7. Pasal 8 (berasal dari Pasal 1sub 1c Undang-Undang Nomor 3 Tahun 1971 jo. Pasal 415 KUHP).

8. Pasal 9 (berasal dari Pasal 1sub 1c Undang-Undang Nomor 3 Tahun 1971 jo. Pasal 416 KUHP).

9. Pasal 10 (berasal dari Pasal 1sub 1c Undang-Undang Nomor 3 Tahun 1971 jo. Pasal 417 KUHP).

10. Pasal 11 (berasal dari Pasal 1sub 1c Undang-Undang Nomor 3 Tahun 1971 jo. Pasal 418 KUHP. 
11. Pasal 12 (berasal dari Pasal 1sub 1c Undang-Undang Nomor 3 Tahun 1971 jo. Pasal 419, Pasal 420, Pasal 423, Pasal, 425 dan Pasal435 KUHP).

12. Pasal 13 (berasal dari Pasal 1sub 1d Undang-Undang Nomor 3 Tahun 1971):

13. Pasal 14 (pasal baru):

- Pelanggaran ketentuan undang-undang yang secara tegas dinyatakan sebagai Tindak Pidana Korupsi, berlaku ketentuan dalam undangundang ini (Undang-undang Nomor 31 Tahun 1999).

14. Pasal 15 perluasan dari Pasal 1sub 2 Undang-Undang Nomor 3 Tahun 1971, yaitu tidak hanya "percobaan" dan "permufakatan jahat" tetapi juga "perbantuan dipidana sama dengan pelaku Tindak Pidana Korupsi.

15. Pasal 16 (pasal baru):

- Tiap orang di luar wilayah Republik Indonesia;

- Yang member bantuan, kesempatan, sarana, atau keterangan untuk terjadinya Tindak Pidana Korupsi;

- Dipidana sama sebagai pelaku Tindak Pidana Korupsi dalam Pasal 2, Pasal 3, Pasal 5 sampai dengan Pasal 14.

16. Pasal 17 sampai dengan Pasal 19: mengatur pidana tambahan.

17. Pasal 20 (pasal baru tentang "pertanggungjawaban" korporasi).

\section{3) Undang-Undang Nomor 20 Tahun 2001}

- Mengubah perumusan Tindak Pidana Korupsi dalam Pasal 5 sampai dengan Pasal 12 Undang-undang Nomor 31 Tahun 1999 dengan tidak mengacu pasalpasal KUHP, tetapi langsung menyubut unsur-unsur delik yang bersangkutan.

- Menyisipkan/menambah pasal-pasal baru ke dalam Undang-undang Nomor 31 Tahun 1999:

1. Pasal $12 \mathrm{~A}$

(1) Ketentuan pidana dalam Pasal 5 sampai dengan Pasal 12 tidak berlaku untuk tindak pidana korupsi yang bernilai kurang dari Rp. 5.000.000,00 (lima juta rupiah)

(2) Tindak Pidana Korupsi, Yang bernilai kurang dari Rp. 5.000.000,00 (lima juta rupiah), dipidana maksimun 3 (tiga) tahun penjara dan denda maksimun Rp. 50.000.000,00 (lima puluh juta rupiah).

2. Pasal 12 B (Gratifikasi):

(1) Gratifikasi kepada Pegawai Negeri/Penyelenggara Negara dianggap pemberian suap, apabila :

- Berhubungan dengan jabatannya, dan

- Berlawanan dengan kewajiban/tugasnya dengan ketentuan:

a. Nilainya Rp. 10.000.000,00 (sepuluh juta rupiah) atau lebih dimana pembuktian (sebagai bukan suap) ada pada penerima (terdakwa); 
b. Nilainya kurang dari Rp. 10.000.000,00 (sepuluh juta rupiah), maka pembuktian suap pada penuntut umum.

Ruang lingkup tindak pidana korupsi yang cukup luas, sebagaimana diatur dalam Nomor 31 Tahun 1999 jo. Undang-undang Nomor 20 Tahun 2001, pada hakikatnya sudah cukup baik. Namun demikian Undang-undang tersebut, masih terdapat persoalan-persoalan yuridis dalam merumuskan tindak pidana korupsi, di mana persoalan-persoalan tersebut dapat mengakibatkan sulitnya operasionalisasi KUHP sebagai sistem induk dalam menjembatani pemberantasan Tindak pidana Korupsi. Persoalan-persoalan tersebut adalah sebagai berikut:

1. Undang-undang Nomor 31 Tahun 1999 jo Undang-undang Nomor 20 Tahun 2001 tentang Tindak Pidana Korupsi belum merumuskan batasan-batasan yuridis atau pengertian yuridis mengenai tindak pidana korupsi dalam hal permufakatan jahat, sedangkan permufakatan jahat yang terdapat dalam KUHP Pasal 88 merupakan istilah yang diatur dalam Bab IX yang tidak mungkin dioperasionalkan mengingat Pasal 103 KUHP mensyaratkan bahwa ketentuanketentuan dalam Bab I sampai Bab VIII berlaku bagi perbuatan-perbuatan yang oleh ketentuan perundang- undangan lainnya diancam dengan pidana. Demikian juga mengenai istilah "pembantuan" yang merupakan istilah yuridis, belum diatur dalam undang-undang ini.

2. Undang-undang Nomor 31 Tahun 1999 jo Undang-undang Nomor 20 Tahun 2001 Tentang Tindak Pidana Korupsi tidak mencantumkan kualifikasi delik apakah sebagai "pelanggaran" atau "kejahatan" sehingga KUHP tidak dapat dioperasionalkan terhadap tindak pidana korupsi khususnya mengenai delik percobaan, karena dalam KUHP hanya percobaan terhadap kejahatan yang dapat dipidana.

Selain persoalan-persoalan yuridis tersebut, sebagaimana diuraikan di atas menurut Barda Nawawi Arief, seharusnya dalam Undang-undang pemberantasan tindak pidana korupsi menjadikan tindak pidana pencucian uang (tindak pidana setelah korupsi) sebagai tindak pidana korupsi.

Bahkan lebih jauh lagi, UNCAC merekomendasikan agar Tindak Pidana Pencucian Uang dimasukkan Ke dalam perundang-undangan tindak pidana korupsi, sebagaimana tercermin pada Pasal 14 dan Pasal 23 berikut ini :

Article 14. Measures to prevent money-laundering

(Pasal 14. Tindakan-tindakan untuk Mencegah Pencucian Uang)

1. Each State Party shall:

(Setiap Negara Pihak wajib):

(a) Institute a comprehensive domestic regulatory and supervisory regime for banks and non-bank financial institutions, including natural or legal persons that provide formal or informal services for the transmission of money or value and, where appropriate, other bodies particularly susceptible to moneylaundering, within its 
competence, in order to deter and detect all forms of money-laundering, which regime shall emphasize requirements for customer and, where appropriate, beneficial owner identification, record-keeping and the reporting of suspicious transactions;

(Membentuk rezim pengaturan dan pengawasan internal yang komprehensif untuk bank-bank dan lembaga-lembaga keuangan nonbank, termasuk orang-orang pribadi dan badan- badan hukum yang memberikan jasa-jasa resmi atau tidak resmi untuk pengiriman uang atau nilai dan, bilamana tepat, badan-badan lain yang secara khusus rawan terhadap pencucian uang, di dalam kewenangannya, untuk menahan dan mendeteksi semua bentuk pencucian uang, rezim mana wajib menekankan persyaratan-persyaratan bagi nasabah dan, sebagaimana layaknya, identifikasi penerima hak, penyimpanan dokumen dan pelaporan transaksi-transaksi yang mencurigakan);

(b) Without prejudice to article 46 of this Convention, ensure that administrative, regulatory, law enforcement and other authorities dedicated to combating moneylaundering (including, where appropriate under domestik law, judicial authorities) have the ability to cooperate and exchange information at the national and international levels within the conditions prescribed by its domestic law and, to that end, shall consider the establishment of a financial intelligence unit to serve as a national centre for the collection, analysis and dissemination of information regarding potential money-laundering.

(Tanpa mengabaikan Pasal 46 Konvensi ini, memastikan bahwa badanbadan berwenang di bidang administratif, pengaturan, penegakan hukum, dan lainnya yang ditujukan untuk memberantas pencucian uang (termasuk, bilamana tepat berdasarkan hukum nasional, badan-badan peradilan) memiliki kemampuan untuk bekerja sama dan menukar informasi apa pun pada tingkat nasional dan internasional dengan syarat-syarat yang ditentukan oleh hukum nasionalnya dan, untuk tujuan itu, wajib mempertimbangkan pembentukan unit intelijen keuangan yang berfungsi sebagai pusat nasional untuk pengumpulan, analisis, dan penyebarluasan informasi mengenai pencucian uang yang mungkin terjadi).

2. States Parties shall consider implementing feasible measures to detect and monitor the movement of cash and appropriate negotiable instrumental across their borders, subject to safeguards to ensure proper use of information and without impeding in any way the movement of legitimate capital. Such measures may include a requirement that individuals and businesses report the cross-border transfer of substantial quantities of cash and appropriate negotiable instruments.

(Negara-Negara Pihak wajib mempertimbangkan untuk melakukan tindakantindakan yang tepat guna untuk mendeteksi dan memantau pergerakan uang tunai dan instrumen-instrumen surat berharga yang melintasi perbatasanperbatasan mereka, tunduk pada pengamanan-pengamanan untuk memastikan 
penggunaan yang wajar atas informasi dan tanpa menghalangi secara apa pun pergerakan modal yang sah. Tindakan-tindakan tersebut dapat mencakup persyaratan bahwa perorangan dan badan-badan usaha melaporkan transfer lintas perbatasan uang tunai dalam jumlah besar dan instrumen-instrumen surat berharga yang sepantasnya).

3. States Parties shall consider implementing appropriate and feasible measures to require financial institutions, including money remitters:

(Negara-Negara Pihak wajib mempertimbangkan untuk melakukan tindakantindakan yang wajar dan tepat untuk mensyaratkan lembaga-lembaga keuangan, termasuk pengirim- pengirim uang):

(a) To include on forms for the electronic transfer of funds and related messages accurate and meaningful information on the originator;

(Untuk memasukkan ke dalam formulir-formulir untuk transfer

Elektronik dana-dana dan pesan-pesan terkait, informasi yang cermat dan berharga mengenai asal usulnya);

(b) To maintain such information throughout the payment chain; and (Untuk menyimpan informasi tersebut sepanjang rangkaian pembayaran; dan)

(c) To apply enhanced scrutiny to transfers of funds that do not contain complete information on the originator.

(Untuk menerapkan ketelitian yang tinggi atas transfer dana- dana yang tidak mencantumkan informasi yang lengkap tentang asal-usulnya).

Article 23. Laundering of proceeds of Crime

(Pasal 23. Pencucian Hasil-hasil Kejahatan)

1. Each State Party shall adopt, in accordance with fundamental principles of its domestic law, such legislative and other measures as may be necessary to establish as criminal offences, when committed intentionally:

(Setiap Negara Pihak wajib mengambil, sesuai dengan prinsip-prinsip dasar hukum nasionalnya, tindakan-tindakan legislatif dan lainnya yang dianggap perlu untuk menetapkan sebagai kejahatan pidana, apabila dilakukan dengan sengaja):

(a) (i) The conversion or transfer of property, knowing that such property is the proceeds of crime, for the purpose of concealing or disguising the illicit origin of the property or of helping any person who is involved in the commission of the predicate offence to evade the legal consequences of his or her action;

(Konversi atau transfer kekayaan, dengan mengetahui bahwa kekayaan tersebut adalah hasil-hasil kejahatan, untuk maksud menyembunyikan atau menyamarkan asal kekayaan yang tidak sah atau membantu orang siapa pun yang terlibat dalam pelaksanaan kejahatan asal untuk menghindari konsekuensi hukum dari tindakannya); 
(ii) The concealment or disguise of the true nature, source, location, disposition, movement or ownership of or rights with respect to property, knowing that such property is the proceeds of crime;

(Penyembunyian atau penyamaran sifat, sumber, lokasi, pelepasan, perpindahan atau pemilikan yang sebenarnya dari atau hak-hak yang berkenaan dengan kekayaan, dengan mengetahui bahwa kekayaan tersebut adalah hasil-hasil kejahatan).

(b) Subject to the basic concepts of its legal system:

Berdasarkan konsep dasar sistem hukumnya:

(i) The acquisition, possession or use of property, knowing, at the time of receipt, that such property is the proceeds of crime;

(Perolehan, pemilikan atau penggunaan kekayaan, dengan mengetahui, pada waktu penerimaan bahwa kekayaan tersebut adalah hasil-hasil kejahatan);

(ii) Participation in, association with or conspiracy to commit, attempts to commit and aiding, abetting, facilitating and counselling the commission of any of the offences established in accordance with this article.

(Ikut serta dalam, berhubungan dengan atau konspirasi untuk melakukan, percobaan untuk melakukan dan membantu, bersekongkol, mempermudah dan menganjurkan pelaksanaan kejahatan-kejahatan apa pun yang dilakukan sesuai dengan Pasal ini).

2. For purposes of implementing or applying paragraph 1 of this article:

(Untuk maksud melaksanakan atau menerapkan ayat (1) Pasal ini) :

(a) Each State Party shall seek to apply paragraph 1 of this article to the widest range of predicate offences;

(Setiap Negara Pihak wajib berupaya untuk menerapkan ayat (1) Pasal ini dalam arti yang seluas-luasnya dari kejahatan asal);

(b) Each State Party shall include as predicate offences at a minimum a comprehensive range of criminal offences established in accordance with this Convention;

(Setiap Negara Pihak wajib memasukkan sebagai kejahatan asal sekurangkurangnya suatu rangkaian komprehensif dari kejahatan- kejahatan pidana yang ditetapkan sesuai dengan Konvensi ini);

(c) For the purposes of subparagraph (b) above, predicate offences shall include offences committed both within and outside the jurisdiction of the State Party in question. However, offences committed outside the jurisdiction of a State Party shall constitute predicate offences only when the relevant conduct is a criminal offence under the domestic law of the State where it is Committee and would be a criminal offence under the domestic law of the State Party implementing or applying this article had it been committed there; 
(Untuk maksud subayat b di atas, kejahatan asal termasuk kejahatankejahatan yang dilakukan baik di dalam dan di luar yurisdiksi Negara Pihak yang bersangkutan. Namun demikian, kejahatan-kejahatan yang dilakukan di luar yurisdiksi suatu Negara Pihak merupakan kejahatan asal hanya apabila tindakan tersebut merupakan kejahatan pidana berdasarkan hukum nasional Negara di mana tindakan tersebut dilakukan dan adalah suatu kejahatan pidana berdasarkan hukum nasional Negara Pihak yang melaksanakan atau menerapkan Pasal ini manakala tindakan tersebut dilakukan di sana);

(d) Each State Party shall furnish copies of its laws that give effect to this article and of any subsequent changes to such laws or a description thereof to the SecretaryGeneral of the United Nations;

(Setiap Negara Pihak wajib menyerahkan salinan undang- undangnya yang memberlakukan Pasal ini dan perubahan- perubahan selanjutnya pada undang-undang tersebut atau penjelasan daripadanya kepada Sekretaris Jenderal Perserikatan Bangsa-Bangsa);

(e) If required by fundamental principles of the domestic law of a State Party, it may be provided that the offences set forth in paragraph 1 of this article do not apply to the persons who committed the predicate offence.

(Apabila disyaratkan oleh prinsip-prinsip dasar hukum nasional suatu Negara Pihak, dapat ditentukan bahwa kejahatan-kejahatanyang dimaksud dalam ayat (1) dari Pasal ini tidak berlaku bagi orang-orang yang melakukan kejahatan asal).

Penegasan Konvensi UNCAC dalam pasal 14 dan 23 tersebut merupakan isyarat bahwa kebijakan hukum pidana terkait tindak pidana pencucian uang akan lebih efektif jika dimasukkan sebagai tindak pidana korupsi yang merupakan rangkaian komprehensif dari kejahatan (comprehensive range of criminal offences). Termasuk di dalamnya, mereka yang turut serta, permufakatan jahat, percobaan, pembantuan, menganjurkan (Participation in, association with or conspiracy to commit, attempts to commit and aiding, abetting, facilitating and counselling the commission of any of the offences).

\section{PENUTUP}

\section{A. Kesimpulan}

1. Kelemahan- kelemahan formulasi tindak pidana korupsi saat ini ialah Kebijakan hukum pidana dalam hal pemberantasan tidak pidana korupsi, masih tersebar di beberapa perundang-undangan, hal ini dapat menimbulkan persoalan terutama dalam aspek keadilan. Tidak adanya aturan/pedoman mengenai ketentuan pidana minimal khusus dan pidana pengganti denda untuk korporasi. 
2. Sebaiknya dilakukan pembaharuan terhadap kebijakan hukum pidana mengenai tindak pidana korupsi untuk yang akan datang, dengan memperhatikan hal-hal sebagai berikut:

a. Rumusan tindak pidana korupsi tetap menekankan pada unsur "merugikan keuangan atau perekonomian negara". Memberikan pengertian yuridis mengenai "Permufakatan jahat", serta "pengulangan tindak pidana" (recidive)".

b. Menjadikan tindak pidana pencucian uang sebagi tindak pidana korupsi, serta mencantumkan pemberatan pidana untuk tindak pidana korupsi khususnya pada lingkup "suap" dan "pemerasan dalam jabatan" yang dilakukan oleh penegak hukum terhadap perkara- perkara hukum yang sedang diperiksa.

\section{B. Saran}

Berdasarkan pada kesimpulan sebagaimana diuraikan di atas, penulis merekomendasikan hal- hal sebagai berikut:

a. Kebijakan hukum pidana dalam hal pemberantasan tindak pidana korupsi yang akan datang, perlu mencantumkan kualifikasi delik, serta memberikan pengertian atau batasan-batasan yuridis mengenai "permufakatan jahat", dan "pengulangan tindak pidana (recidive)".

b. Rumusan tindak pidana korupsi tetap menekankan pada unsur "merugikan keuangan atau perekonomian negara".

c. Mencantumkan pemberatan pidana dalam lingkup "suap" dan "pemerasan dalam jabatan".

d. Menjadikan tindak pidana pencucian uang sebagai tindak pidana korupsi.

\section{Daftar Pustaka}

Ali, Ahmad. 2008, Menguak Tabir Hukum, Bogor, Ghalia Indinesia.

Amidhan.2006, Catatan Akhir Tahun 2006 Tentang Pelindungan dan Pemenuhan Hak Ekonomi, Sosial dan Budaya, Jakarta, Komnas Ham.

Asikin, Zainal \& Amirudin, 2004, Pengantar Penelitian Hukum, Jakarta, Radja Grafindo Persada.

Atmasasmita, Romli.1995, Kapita Selekta Hukum Pidana dan Kriminologi, Bandung, Mandar Maju.

Baringbing, R.E.2001, Catur Wangsa yang Bebas Kolusi Simpul Mewujudkan Supremasi Hukum, Jakarta, Pusat Kajian Reformasi. 
Barker, Thomas, \& L Carter, David. 1999, Police Deviance (Penyimpangan Polisi), Jakarta, Cipta Manunggal.

Buyung, Adnan Nasution.2004, Pergulatan Tanpa Henti, Pahit Getir Merintis Demokrasi, Jakarta. Aksara Karunia.

Chaerudin, dkk.2008, Strategi Pencegahan dan Penegakan Hukum Tindak Pidana Korupsi, Bandung, Refika aditama.

Hadisuprapto, Paulus. 2008, Deliquensi Anak Pemahaman dan Penanggulangannya, Malang, Bayumedia Publishing.

Hamzah, Andi.1995, Delik-delik Tersebar di Luar KUHP dengan Komentar, Jakarta, Pradnya Paramita.

Hanitijo Soemitro, Ronny. 1982, Metodologi Penelitian Hukum, Jakarta, Ghalia Indonesia.

Hartanti, Evi. 2005, Tindak Pidana Korupsi, Jakarta, Sinar Grafika.

Hartono, Sunaryati. 1994, Penelitian Hukum di Indonesia Pada Akhir Abad ke-20, Bandung, Alumni. 